\title{
In vitro regeneration and molecular characterization of Jatropha curcas plant
}

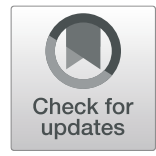

Mohamed El-Sayed', Usama I. Aly ${ }^{1 *}$, Mervat S. Mohamed ${ }^{2}$ and Mohamed R. Rady ${ }^{1}$

\begin{abstract}
Background and objective: A simple, rapid, efficient, and reproducible protocol for callus induction and regeneration of plantlets from callus of Jatropha curcas plant was established.

Materials and methods: Randomly amplified polymorphic DNA (RAPD) and inter simple sequence repeat (ISSR) analyses were used to determine the genetic variation between the regenerated, micropropagated, and mother plants.

Results: The highest callus induction percentage from leaf explant was recorded with MS medium containing $2.5 \mathrm{mg} / \mathrm{l}$ BA (6-benzylaminopurine) + $1.0 \mathrm{mg} / \mathrm{l} \mathrm{NAA}$ (1-naphthaleneacetic acid). Leaf-derived callus was grown on medium containing $2.0 \mathrm{mg} / \mathrm{l} \mathrm{BA}+0.2 \mathrm{mg} / \mathrm{I} \mathrm{IBA}$ (indole-3-butyric acid) for adventitious shoot regeneration. In addition, using five random RAPD primers with the tested samples produced 117 amplified products out of which 25 were polymorphic bands resulting in $21.37 \%$ polymorphism, whereas the five ISSR primers used yielded 116 scorable bands out of which 22 were polymorphic bands producing a polymorphism pecentage of 18.96 .

Conclusion: An optimized protocol for large-scale production of J. curcas plants using plant biotechnology tools was achieved. RAPD and ISSR techniques would introduce an alternative system for large-scale production and establishment of genetically stable plants.
\end{abstract}

Keywords: Jatropha curcas, Callus induction, Regeneration, RAPD, ISSR

\section{Background}

Jatropha curcas L. belongs to family Euphorbiaceae and grows as a large shrub or small tree. The plant is found in tropical and subtropical areas, where it is used for reclaiming land and feedstuff; besides, the plant has different medicinal properties and many other uses. Due to the high oil content of J. curcas seeds (up to $60 \%$ oil) and low production cost, the plant attracted global attention for the development as a source for bio-fuel (Li et al. 2007).

Recent interest in promotion of $J$. curcas as a biodiesel crop demands genetic improvement of the crop for increased seed yield and oil content. Germplasm characterization is necessary to enhance germplasm management and utilization (Basha et al. 2009). A large number of polymorphic markers are required to

\footnotetext{
* Correspondence: usamajp@yahoo.com

${ }^{1}$ Plant Biotechnology Department, National Research Center, 33 El Bohouth St., Dokki, Cairo, P.O 12622, Egypt

Full list of author information is available at the end of the article
}

measure genetic relationships and genetic diversity in a reliable manner. This limits the use of morphological characters and isozymes, which are few or lack adequate levels in J. curcas (Gupta et al. 2008). DNA markers provide an opportunity to characterize genotypes and to measure genetic relationships more precisely than other markers (Soller and Beckmann 1983).

Over the last 15 years, polymerase chain reaction technology has led to the rise of two simple and quick techniques called randomly amplified polymorphic DNA (RAPD) (Li and Nelson 2002) and inter simple sequence repeats (ISSR) (Van der Nest et al. 2000) that were used in evaluation of Jatropha germplasm easily as their application does not need any prior sequence information (Gupta et al. 2008).

Jatropha is seen as a talented opportunity for the production of bio-fuel and is universally accepted as an energy crop. Potential improvement of Jatropha plant is

\section{Springer Open}

๑ The Author(s). 2020 Open Access This article is licensed under a Creative Commons Attribution 4.0 International License, which permits use, sharing, adaptation, distribution and reproduction in any medium or format, as long as you give appropriate credit to the original author(s) and the source, provide a link to the Creative Commons licence, and indicate if changes were made. The images or other third party material in this article are included in the article's Creative Commons licence, unless indicated otherwise in a credit line to the material. If material is not included in the article's Creative Commons licence and your intended use is not permitted by statutory regulation or exceeds the permitted use, you will need to obtain permission directly from the copyright holder. To view a copy of this licence, visit http://creativecommons.org/licenses/by/4.0/. 
currently a key target for scientists via agricultural practices and biotechnological approaches (Nitish and Muppala 2013). Conventional breeding has to be integrated with latest biotechnological approaches to introduce novel traits. The biotechnological means include propagation of selected genotypes using tissue culture techniques and further genetic engineering schemes. Biotechnological crop improvement thus appears as effective and alternative approaches. A particular emphasis on plant regeneration protocol from isolated plant cells or tissue is a prerequisite.

The present investigation has been organized to optimize a protocol for large-scale production of $J$. curcas plants using plant biotechnology techniques including callus induction and plant regeneration from callus tissues; the molecular analysis of the tissue culture raised plants in comparison with mother plants was investigated.

\section{Materials and methods}

\section{Plant materials and culture conditions}

Three months old J. curcas seedlings were kindly provided from the nursery of Ministry of Agriculture, Giza, Egypt. All media used were Murashige and Skoog (1962) (MS) medium with $30 \mathrm{~g} / \mathrm{l}$ sucrose, and $7 \mathrm{~g} / \mathrm{l}$ agar was added. The $\mathrm{pH}$ of medium was adjusted within a range of 5.6 to 5.8 by addition of $0.1 \mathrm{~N}$ potassium hydroxide $(\mathrm{KOH})$ and $0.1 \mathrm{~N}$ hydrochloric acid $(\mathrm{HCl})$. All media and all instruments (scalpel, forceps, scissors, and papers to work on) were sterilized by autoclaving at $121^{\circ} \mathrm{C}$ and 15 psi for $20 \mathrm{~min}$. All cultures were incubated under controlled conditions in the growth chamber. Temperature was $25 \pm 2{ }^{\circ} \mathrm{C}$, with photoperiod of $16 \mathrm{~h}$ light $/ 8$ dark, controlled automatically. Illumination intensity was 2000 lux from cool fluorescent lamps (120-cm long).

\section{Sterilization of $J$. curcas explants}

Leaf explants were excised from J. curcas seedlings and rinsed in tap water, agitated in a disinfectant solution of 3\% salvon (Carbendazim, BASF India Ltd.) for $30 \mathrm{~min}$, and then soaked in $70 \%$ ethanol under aseptic conditions in a vertical air Laminar Flow Cabinet. Explants were immersed for $5 \mathrm{~min}$ in $0.1 \%$ mercuric chloride $\left(\mathrm{HgCl}_{2}\right)$, and then soaked for $10 \mathrm{~min}$ in $1.5 \%$ sodium hypochlorite solution $(\mathrm{NaOCl})$. After each disinfection step, three rinses with sterile distilled water were applied. Sterilized leaf explants were excised to segments about $1 \mathrm{~cm}^{2}$ for callus induction.

\section{Callus induction}

Three leaf explants were cultured on MS medium supplemented with different concentrations of BA and NAA. After 4 weeks of cultivation time taken for callus initiation (days), callus induction (\%), fresh weight, dry weight $(\mathrm{g})$, callus color, and morphology were recorded.
The least significant difference (LSD) test at 0.05 level probabilities was used to compare mean values of all treatments.

\section{Regeneration of plantlets from callus cultures}

Leaf-derived calli of $J$. curcas were cultured on MS medium supplemented with different combinations of BA with 2,4-D or IBA for regeneration protocol. After 6 weeks of cultivation, regeneration percentage and number of regenerated adventitious shoots were recorded. Adventitious shoots raised from this experiment were applied to rooting experiment as done before (Rady et al. 2016).

\section{Molecular analysis}

Two PCR-based techniques, RAPD and ISSR, used for the evaluation of the genetic variance among tissue culture raised regenerated plants and micropropagated plants from our previous study (Rady et al. 2016) in comparison with mother plants. The use of these two types of molecular markers, which amplify different regions of the genome, allows better chances for identification of genetic variation between tested plants.

\section{Genomic DNA isolation}

Total genomic DNA was isolated from leaf explants according to Doyle and Doyle (1990).

\section{RAPD-PCR analysis}

A set of 5 random primers have been used for the evaluation of polymorphism percentage among the tested samples. RAPD-PCR amplification reactions were carried out according to the procedure described by Williams et al. (1990) with minor modifications. Reactions were occurred under PCR optimized conditions in $25 \mu \mathrm{l}$ reaction volume containing $1 \times$ PCR buffer (Promega, USA), $1.5 \mathrm{mM} \mathrm{MgCl}_{2}, 2.0 \mathrm{mM}$ deoxyribonucleoside triphosphates (dNTPs) (Promega, USA), 1.0 U Taq DNA polymerase (Bangalore Genei, India), $25 \mathrm{ng}$ template DNA, and $1.0 \mu \mathrm{M}$ primer from each of random primers (Operon) (Table 1), and finally, the volume completed up to $25 \mu \mathrm{l}$ with double distilled water.

Amplification reaction was carried out using a Gene Amp PE applied Biosystem 9700 A (Perkin-Elmer, USA) thermocycler machine programmed to fulfill 40 cycles after an initial denaturation cycle for $5 \mathrm{~min}$ at $94^{\circ} \mathrm{C}$. Each cycle consisted of a denaturation step at $94{ }^{\circ} \mathrm{C}$ for $1.0 \mathrm{~min}$, an annealing step at $36^{\circ} \mathrm{C}$ for $1.0 \mathrm{~min}$, and an elongation step at $72^{\circ} \mathrm{C}$ for $1.5 \mathrm{~min}$. The PCR products were incubated at $4{ }^{\circ} \mathrm{C}$ for further electrophoresis.

The amplification products were resolved by electrophoresis in a $1.5 \%$ agarose gel containing ethidium bromide $(0.5 \mu \mathrm{g} / \mathrm{ml})$ in $1.0 \times \mathrm{TBE}$ buffer in the agarose gel electrophoresis system at $90 \mathrm{~V}$ for $1 \mathrm{~h}$. DNA bands 
Table 1 Sequence of primers used in randomly amplified polymorphic DNA (RAPD) analysis

\begin{tabular}{ll}
\hline $\begin{array}{l}\text { Primer } \\
\text { code }\end{array}$ & Primer sequence \\
\hline C12 & $5^{\prime}-1-3^{\prime}$ \\
A6 & GAGGCGTCGC \\
AM7 & TGGCCACCTG \\
AM8 & CTTCGGCAGCATCTCTTCAT \\
AM9 & CAGTGTGGAGCCGATTATG \\
AM1 & ATGTGTTGTCTGGCTTGTA \\
AM2 & CTCTCTCTCTCTCTCTG \\
AM3 & GGATGGAATAGTCTC \\
AM4 & GCATGGCAAGCTGCA \\
AM5 & GAGAGAGAGAGAGAGAC \\
\hline
\end{tabular}

were detected and photographed under UV light with gel documentation system. The size of amplification products was estimated using $3.0 \mathrm{kbp}$ DNA ladder. The banding patters generated by RAPD analysis were compared to evaluate the genetic variance between samples. The amplified fragments were scored either as present $(+)$ or absent (-). The genetic similarity coefficient (GS) between the tested samples was estimated according to Dice coefficient (Jaccard 1908). The similarity matrix was used in the cluster analysis which was used to organize the observed data into meaning for structures.

\section{ISSR-PCR analysis}

A set of 5 ISSR primers were used in the evaluation of polymorphism percentage among the tested samples. The amplification reaction (PCR) was performed in $25 \mu \mathrm{l}$ reaction volume containing the following: $1 \times$ PCR buffer, $1.75 \mathrm{mg} / \mathrm{l} \mathrm{MgCl}$, $5 \mathrm{mM}$ of each dNTPs, $1.0 \mathrm{U}$ of Taq DNA polymerase, $25 \mathrm{ng}$ of template DNA, and $40 \mu \mathrm{M}$ of oligonucleotide ISSR primer (Operon) (Table 1), and finally, the volume completed up to $25 \mu \mathrm{l}$ with double distilled water. PCR reaction was carried out in the thermocycler machine programmed to fulfill 35 cycles after an initial denaturation step for $5 \mathrm{~min}$ at $94^{\circ} \mathrm{C}$ followed by ten touchdown cycles $\left(94{ }^{\circ} \mathrm{C} / 30 \mathrm{~s}, 65-55^{\circ} \mathrm{C} /\right.$ $\left.45 \mathrm{~s}, 72{ }^{\circ} \mathrm{C} / 1 \mathrm{~min}\right)$. The PCR products were incubated at $4{ }^{\circ} \mathrm{C}$. The amplification products were resolved by electrophoresis as mentioned before with RAPD analysis. The size of amplification products was estimated using the $3.0 \mathrm{kbp}$ DNA ladder.

\section{Results}

\section{Callus induction}

The effect of different combinations of BA and NAA on callus initiation from leaf explants of $J$. curcas after 1 month of cultivation was investigated. The MS basal medium induces any callus tissues. The highest callus induction percentage was 97.5 on MS medium supplemented with $2.5 \mathrm{mg} / \mathrm{l} \mathrm{BA}+1.0 \mathrm{mg} / \mathrm{l}$ NAA (Fig. 1a). On the other hand, the lowest callus induction percentage (10) was observed with MS medium supplemented with $0.25 \mathrm{mg} / \mathrm{l} \mathrm{BA}+0.5 \mathrm{mg} / \mathrm{l} \mathrm{NAA}$ (Fig. 1b). Moreover, the MS medium supplemented with $1.0 \mathrm{mg} / \mathrm{l} \mathrm{BA}+0.5 \mathrm{mg} / \mathrm{l}$ NAA was the best medium giving the highest fresh weight from leaf explants (Fig. 1c), whereas the lowest fresh weight was obtained on MS medium supplemented with $0.25 \mathrm{mg} / \mathrm{l} \mathrm{BA}+0.5 \mathrm{mg} / \mathrm{l}$ NAA (Fig 1b).

Concerning callus color and morphology, a creamy white friable callus was showed in Fig 1a, c. Green friable (Fig. 1d) and creamy yellowish compact callus (Fig. 1e) was formed. In addition to creamy greenish compact callus (Fig. 1b), a deep green friable callus (Fig. 1f) was also noted.

\section{Regeneration of plantlets from callus cultures Effect of different concentrations of BA and 2,4-D or IBA on regeneration}

From Table 2, it could be observed that the highest regeneration percentage was 83.33 recorded by MS medium supplemented with $2.0 \mathrm{mg} / \mathrm{l} \mathrm{BA}+0.2 \mathrm{mg} / \mathrm{l} \mathrm{IBA}$ (Fig. 2a), followed by $66.67 \%$ that was reported by MS medium supplemented with $1.0 \mathrm{mg} / \mathrm{l} \mathrm{BA}+0.1 \mathrm{mg} / \mathrm{l} \mathrm{IBA}$ (Fig. 2b), whereas MS medium supplemented with 0.5 $\mathrm{mg} / \mathrm{l} \mathrm{BA}+1.0 \mathrm{mg} / \mathrm{l}$ 2,4-D gave the lowest regeneration percentage (21.67) (Fig 2c). Moreover, MS medium free of growth regulators did not show any response for regeneration of adventitious shoots (Fig 2d). Moreover, MS medium supplemented with $2.0 \mathrm{mg} / \mathrm{l} \mathrm{BA}+0.2 \mathrm{mg} / \mathrm{l}$ IBA gave the highest number of regenerated adventitious shoots (13.00), followed by 11.67 that was recorded with MS medium supplemented with $1.0 \mathrm{mg} / \mathrm{l} \mathrm{BA}+0.1 \mathrm{mg} / \mathrm{l}$ IBA. On the other hand, no regeneration of adventitious shoots was occurred when callus tissues was grown on medium without growth regulators.

\section{Genetic variation based on RAPD analysis}

Data in Table 3 demonstrated the results of RAPD analysis of six different samples of $J$. curcas plants mentioned as two samples from each of mother plant, in vitro propagated plant, and plants regenerated from callus. Out of the 10 random primers screened, only five primers produced clear reproducible bands. The five primers yielded 117 scorable bands (with an average of 23.4 bands per primer), including twenty-five polymorphic bands. The number of scorable bands from each primer varied from 16 to 38 . The primer $\mathrm{C} 12$ in particular produced the highest number of strongly amplified individual fragments (38), whereas, primer AM9 produced the lowest number of amplicons (16). On the other hand, primer AM8 gave the highest percentage of polymorphism (38.88) while the lowest 

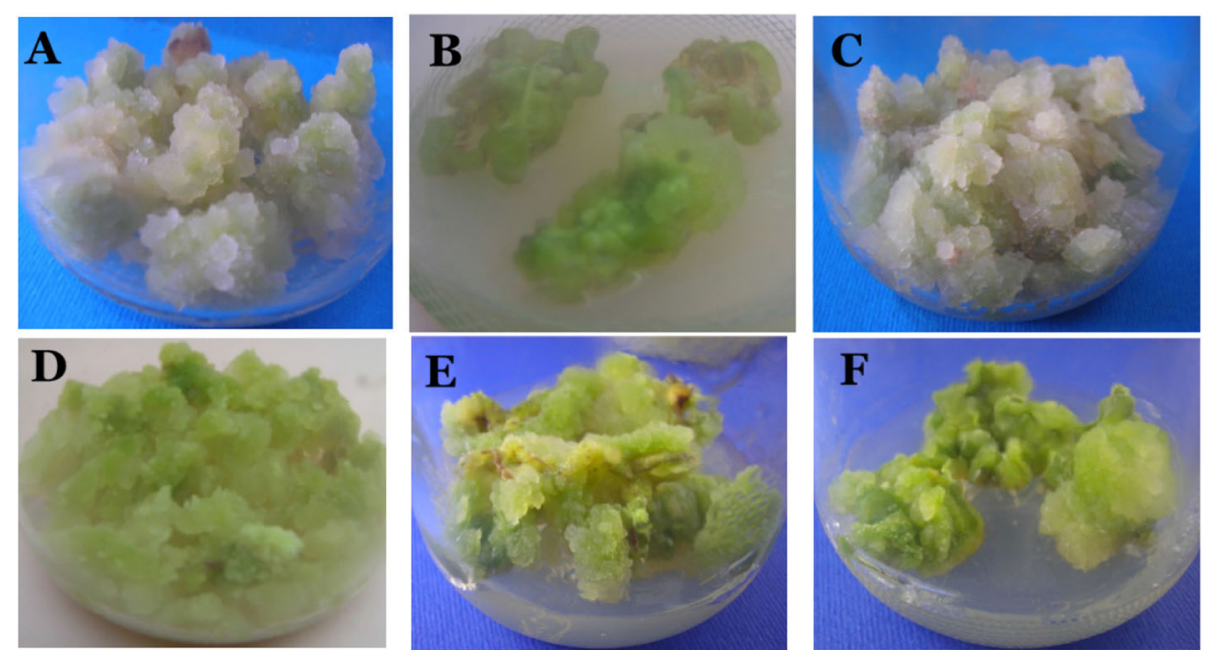

Fig. 1 Callus induction from leaf explant on MS medium containing:2.5 mg/l BA + 1.0 mg/l NAA (a), 0.25 mg/l BA + 0.5 mg/l NAA (b), $1.0 \mathrm{mg} / \mathrm{l} \mathrm{BA}$ $+0.5 \mathrm{mg} / \mathrm{l} \mathrm{NAA}(\mathbf{c})$, green friable callus grown on MS $+2.5 \mathrm{mg} / \mathrm{l} \mathrm{BA}+0.5 \mathrm{mg} / \mathrm{l} \mathrm{NAA}(\mathbf{d})$, creamy yellowish compact callus grown on MS + 0.25 , 0.5 , or $1.0 \mathrm{mg} / \mathrm{l} \mathrm{BA}$ in combination with $1.0 \mathrm{mg} / \mathrm{l} \mathrm{NAA}(\mathbf{e})$, and a deep green friable callus grown on MS + $3.0 \mathrm{mg} / \mathrm{l} \mathrm{BA}+1.0 \mathrm{mg} / \mathrm{l} \mathrm{NAA}$ (f) after 4 weeks of cultivation

percentage of polymorphism (14.29) was recorded with primer AM7. Using primer C12, 6 polymorphic bands out of 38 scorable bands were detected, representing polymorphism percentage of 15.79 . Out of these six bands, three were absent with molecular weight 1134, 907, and 817 bp in regenerated plant number 2 (C2) lane 6 also, and three present polymorphic bands were detected with molecular weights of 881,869 , and $734 \mathrm{bp}$ in C2 plant (lane 6), B2 plant (lane 4), and B1 plant (lane 3) respectively (Fig. 3a). And primer A6 produced a polymorphism percentage of 25, giving 6 polymorphic bands out of 24 amplification products. Two polymorphic bands of molecular weights of 900 and $468 \mathrm{bp}$ in plant C2 (lane 6) were absent, whereas the other four polymorphic bands of molecular weights of 945,658 , and $525 \mathrm{bp}$ in plant B2 (lane 4) and one at $451 \mathrm{bp}$ in

Table 2 Effect of different concentrations of BA and 2,4-D or IBA on shoots regeneration from leaf-derived callus of $J$. curcas after 6 weeks of cultivation

\begin{tabular}{|c|c|c|c|c|}
\hline \multicolumn{3}{|c|}{ Growth regulators (mg/l) } & \multirow{2}{*}{$\begin{array}{l}\text { Regeneration } \\
(\%)\end{array}$} & \multirow{2}{*}{$\begin{array}{l}\text { No. of } \\
\text { regenerated } \\
\text { shoots }\end{array}$} \\
\hline $\mathrm{BA}$ & $2,4-D$ & $\mathrm{IBA}$ & & \\
\hline 0.0 & 0.0 & 0.0 & 0.00 & 0.00 \\
\hline 0.5 & 1.0 & 0.0 & 21.67 & 3.67 \\
\hline 1.0 & 2.0 & 0.0 & 33.33 & 7.67 \\
\hline 2.0 & 3.0 & 0.0 & 58.33 & 9.33 \\
\hline 0.5 & 0.0 & 0.05 & 41.67 & 8.00 \\
\hline 1.0 & 0.0 & 0.1 & 66.67 & 11.67 \\
\hline 2.0 & 0.0 & 0.2 & 83.33 & 13.00 \\
\hline 3.0 & 0.0 & 0.4 & 50.00 & 7.33 \\
\hline
\end{tabular}

plants C2 (lane 6) were present (Fig. 3b). In addition, with primer AM7, 3 polymorphic bands out of 21 scorable bands were detected, representing a polymorphism percentage of 14.29. Three polymorphic bands with molecular weights of 726,632 , and $487 \mathrm{bp}$ were absent in plant A1 (lane 1) (Fig. 3c), while primer AM8 produced 7 polymorphic bands out of 18 scorable bands, representing polymorphism a percentage of 38.88 . Out of these 7 bands, 2 were absent with molecular weights of 865 and $374 \mathrm{bp}$ in in vivo plants 1 (A1, lane 1) and in vivo plant 2 (A2, lane 2 ) respectively. Other five polymorphic bands were present with molecular weights of $575,231,224,217$, and $157 \mathrm{bp}$ in in vivo plant 1 (A1, lane 1$)$, in vitro plant 2 (B2, lane 4), regenerated plant 2 (C2, lane 6), regenerated plant 1 ( $\mathrm{C} 1$, lane 5$)$, and $\mathrm{C} 1$ (lane 5) respectively (Fig 3d). Finally, primer AM9 resulted in three polymorphic bands out of 16 scorable bands, representing a polymorphism percentage of 18.75. The three polymorphic bands were present with molecular weights of $843 \mathrm{bp}$ presented in plant C2 (lane 6) and 620 and $412 \mathrm{bp}$ in in vivo plant 1 (A1, lane 1) respectively (Fig. 3e).

\section{Unique markers as revealed by RAPD}

Data tabulated in Table 4 showed the tested samples of J. curcas which characterized by unique positive and/or negative RAPD markers and the total number of markers identifying each sample. Different primers revealed various numbers of unique positive and/or negative markers across the six samples of tested plants. The total number of unique markers was 25, and 15 of them were representing unique positive marker and 10 represented the unique negative marker. The highest number 


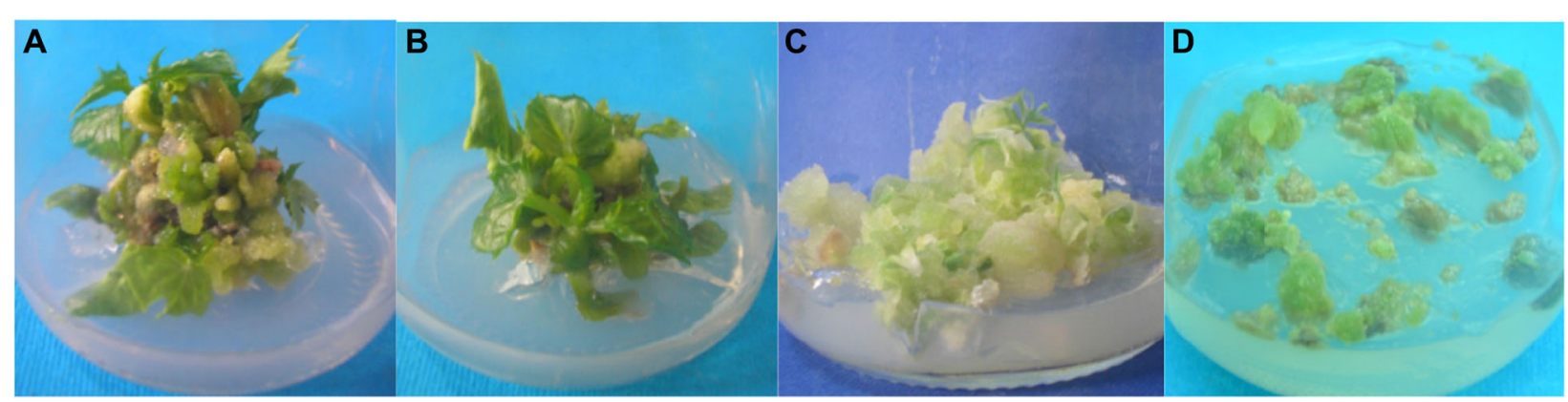

Fig. 2 Shoots regenerated from J. curcas leaf-derived callus cultured on MS medium with $2.0 \mathrm{mg} / \mathrm{l}$ BA $+0.2 \mathrm{mg} / \mathrm{lBA}$ (a), $1.0 \mathrm{mg} / \mathrm{l}$ BA + 0.1 mg/l IBA (b), $0.5 \mathrm{mg} / \mathrm{l} \mathrm{BA}+1.0 \mathrm{mg} / \mathrm{l}$ 2,4-D (c), and control (d), after 6 weeks of cultivation

of unique markers (9) was exhibited with regenerated plant 2 (C2). C2 showed 9 unique markers, and 4 of them were unique positive and were scored at molecular sizes of $881,451,224$, and 843 bp with primers C12, A6, AM8 and AM9 respectively. The rest (5) were unique negative markers that were scored with primer $\mathrm{C} 12$ at molecular sizes of 1134, 907, and $817 \mathrm{bp}$ and primer A6 at molecular sizes of 900 and $468 \mathrm{bp}$. In addition, with in vivo plant 1 (A1), 3 unique positive markers out of 7 unique markers were reported. One of them was scored at $575 \mathrm{bp}$ with primer AM8 and 2 were scored at 620 and $412 \mathrm{bp}$ with primer AM9, whereas for the 4 unique negative markers, 3 of them were scored at 726, 632, and $487 \mathrm{bp}$ with primer AM7 and one were scored at molecular size of $865 \mathrm{bp}$ with primer AM8. And with in vitro plant 2 (B2), it exhibited five unique markers; all of them were unique negative markers. One of them was scored with primer $\mathrm{C} 12$ at $869 \mathrm{bp}, 3$ of them were scored at 945,658 , and $525 \mathrm{bp}$ with primer A6, and one was scored at $231 \mathrm{bp}$ with primer AM8. Moreover, the lowest number of unique markers was the one which appeared with in vivo plant 2 (A2) as a unique negative marker scored at $374 \mathrm{bp}$ with primer AM8; also, one unique marker was exhibited in in vitro plant 1 (B1) as a unique positive marker scored at 734 bp with primer $\mathrm{C} 12$. From the obtained data, it could be observed that regenerated plant 1 (C1) exhibited 2 unique markers with primer AM8 scored as unique positive markers at molecular sizes 217 and $157 \mathrm{bp}$.

\section{Cluster analysis of $J$. curcas tested samples}

The dendrogram constructed from UPGMA cluster analysis of the Dice similarity coefficients calculated from RAPD data is shown in Fig. 4. The dendrogram based on genetic similarities separated the six samples of $J$. curcas into two main groups.

The regenerated plant $2(\mathrm{C} 2)$ was grouped in the first cluster alone, and all other samples were grouped in the second cluster, which was separated into two subclusters; the first sub-cluster included in vivo plant 1 (A1) and the second included the other 4 samples (A1, $\mathrm{B} 1, \mathrm{~B} 2$, and $\mathrm{C} 1$ ). The 4 samples were classified into two sub-clusters, the first included regenerated plant 1 (C1) and the second included the other 3 samples subcluster. This sub-cluster divided into two sub-clusters; the first included in vitro plant 2 (B2) and the second included in vivo plant 2 (A2) and in vitro plant 1 (B1).

Table 3 RAPD-PCR amplification products of DNA extracted from different samples of J. curcas plants using different five random primers

\begin{tabular}{|c|c|c|c|c|c|}
\hline Primer code & $\begin{array}{l}\text { Primer sequence } \\
5^{\prime}-3^{\prime}\end{array}$ & $\begin{array}{l}\text { Total number of Scorable } \\
\text { bands }\end{array}$ & $\begin{array}{l}\text { Number of monomorphic } \\
\text { bands }\end{array}$ & $\begin{array}{l}\text { Number of polymorphic } \\
\text { bands }\end{array}$ & $\begin{array}{l}\text { Polymorphism } \\
(\%)\end{array}$ \\
\hline$\overline{C 12}$ & GAGGCGTCGC & 38 & 18 & 6 & 15.79 \\
\hline A6 & TGGCCACCTG & 24 & 6 & 6 & 25.00 \\
\hline AM7 & $\begin{array}{l}\text { CTTCGGCAGC- } \\
\text {-ATCTCTTCAT }\end{array}$ & 21 & 6 & 3 & 14.29 \\
\hline AM8 & $\begin{array}{l}\text { CAGTGTGGAA- } \\
\text {-GCCGATTATG }\end{array}$ & 18 & 0 & 7 & 38.88 \\
\hline AM9 & $\begin{array}{l}\text { ATGTGTTGTC- } \\
\text {-TGGCTTGGTA }\end{array}$ & 16 & 6 & 3 & 18.75 \\
\hline $\begin{array}{l}\text { Overall } \\
\text { totals }\end{array}$ & --- & 117 & 36 & 25 & 21.37 \\
\hline
\end{tabular}

Polymorphism $\%=$ (number of polymorphic bands/total number of scorable bands) $\times 100$ 


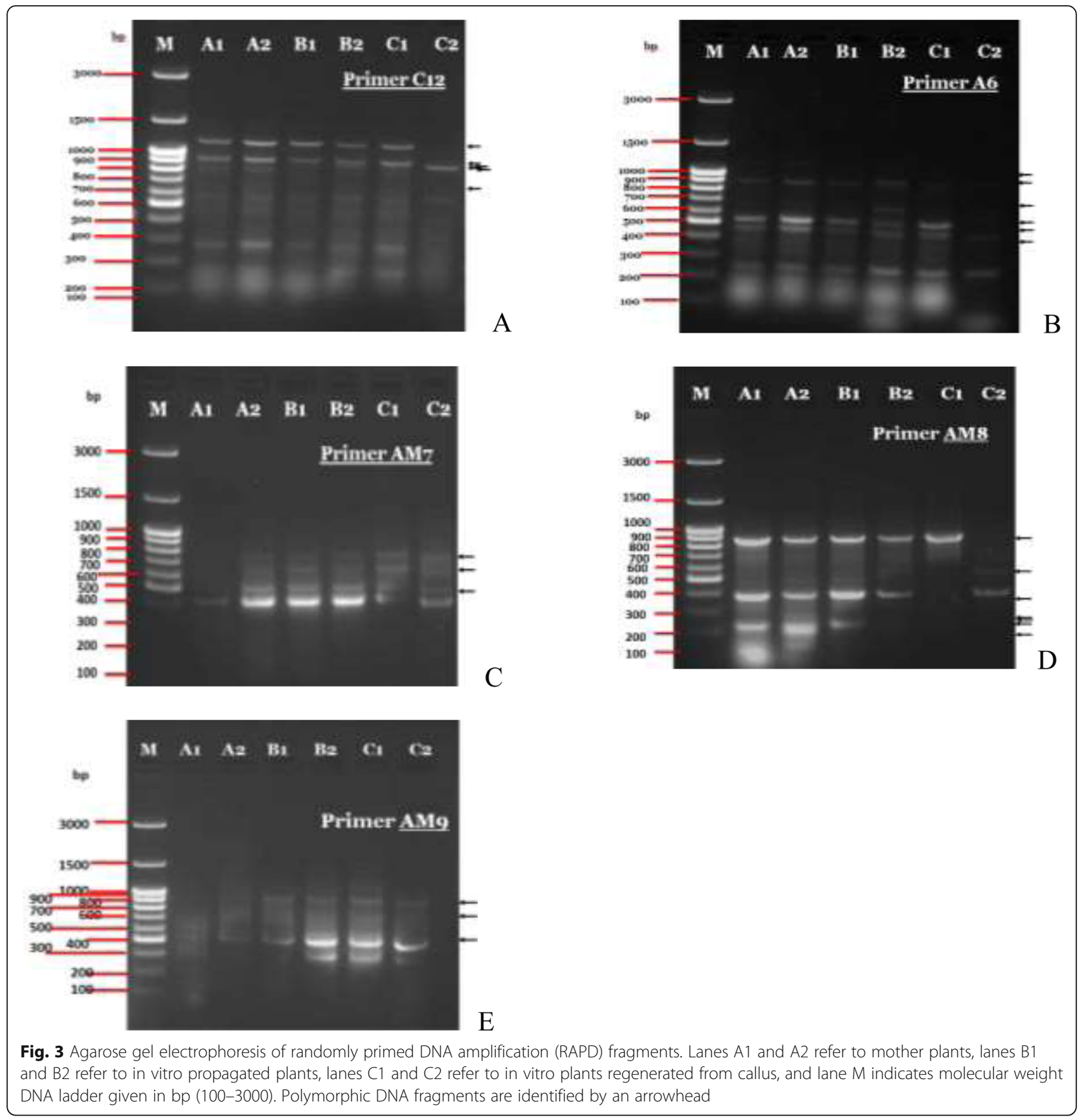

Inter simple sequence repeat (ISSR) analysis

Data in Table 5 demonstrated the results of ISSR analysis of three different samples of J. curcas plants. Out of ten ISSR primers screened, only five primers produced clear reproducible bands. The five primers yielded 116 scorable bands (with an average of 23.2 bands per primer), including 22 polymorphic bands. The number of scorable bands from each primer varied from 14 to 30 , while Fig. 5 showed the distribution and band sizes of produced by each primer. The number of bands varied from 14 (primer AM2) to 30 (primer AM1), and sizes ranged from 185 to $1571 \mathrm{bp}$. The average numbers of polymorphic bands per primer was 4.4. The percentage of polymorphism ranged from 10 recorded with primer AM1 to 31.82 recorded with AM5 primer with an average polymorphism of $18.96 \%$ across all tested samples.

Using primer AM1, 3 polymorphic bands out of 30 scorable bands were detected, representing polymorphism percentage of 10 . The three bands were absent at 
Table 4 Unique markers based on RAPD for different samples of J. curcas

\begin{tabular}{|c|c|c|c|c|c|c|}
\hline \multirow{2}{*}{$\begin{array}{l}\text { Code } \\
\text { (lane) }\end{array}$} & \multirow[t]{2}{*}{ Sample } & \multirow[t]{2}{*}{ Primer } & \multirow{2}{*}{$\begin{array}{l}\text { UPM } \\
\text { (bp) }\end{array}$} & \multirow{2}{*}{$\begin{array}{l}\text { UNM } \\
\text { (bp) }\end{array}$} & \multicolumn{2}{|c|}{ Total for } \\
\hline & & & & & Primer & $\overline{\text { Sample }}$ \\
\hline \multirow[t]{3}{*}{ A1 (1) } & In vivo (1) & AM7 & - & $\begin{array}{l}726 \\
632 \\
487\end{array}$ & 3 & 7 \\
\hline & & AM8 & 575 & 865 & 2 & \\
\hline & & AM9 & $\begin{array}{l}620 \\
412\end{array}$ & - & 2 & \\
\hline A2 (2) & In vivo (2) & AM8 & - & 374 & 1 & 1 \\
\hline B1 (3) & In vitro (1) & $\mathrm{C} 12$ & 734 & - & 1 & 1 \\
\hline \multirow[t]{3}{*}{ B2 (4) } & In vitro (2) & $\mathrm{C} 12$ & 869 & - & 1 & 5 \\
\hline & & A6 & $\begin{array}{l}945 \\
658 \\
525\end{array}$ & - & 3 & \\
\hline & & AM8 & 231 & - & 1 & \\
\hline C1 (5) & Regenerated (1) & AM8 & $\begin{array}{l}217 \\
157\end{array}$ & - & 2 & 2 \\
\hline \multirow[t]{4}{*}{ C2 (6) } & Regenerated (2) & $\mathrm{C} 12$ & 881 & $\begin{array}{l}1134 \\
907 \\
817\end{array}$ & 4 & 9 \\
\hline & & A6 & 451 & $\begin{array}{l}900 \\
468\end{array}$ & 3 & \\
\hline & & AM8 & 224 & - & 1 & \\
\hline & & AM9 & 843 & - & 1 & \\
\hline Total & & & 15 & 10 & & 25 \\
\hline
\end{tabular}

UPM unique positive marker, UNM unique negative marker

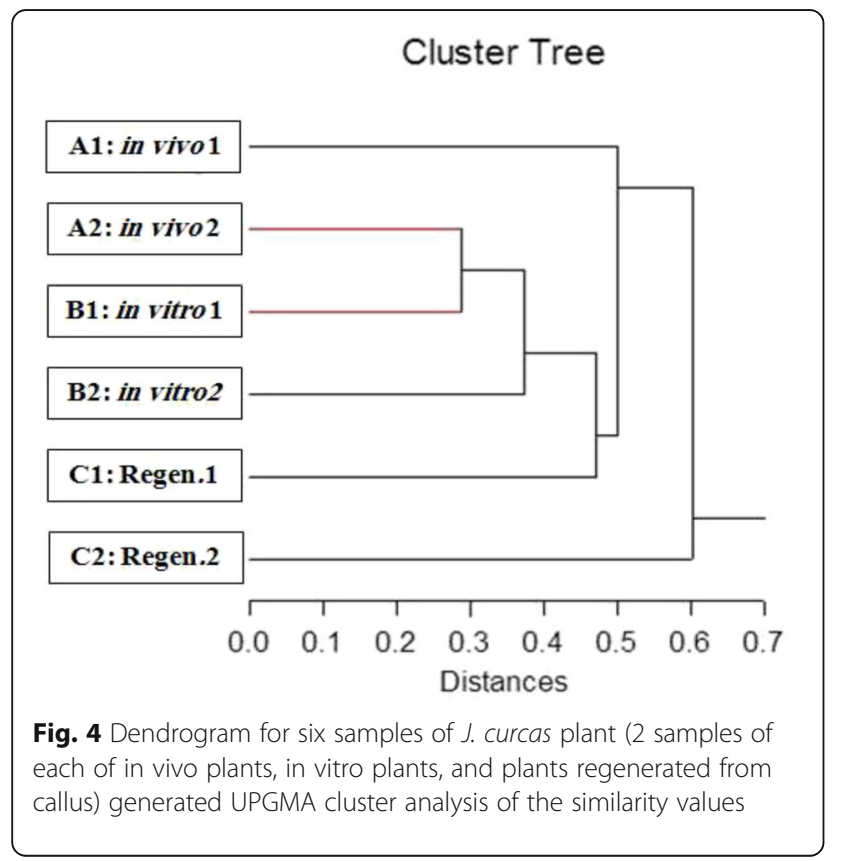

molecular size of $900 \mathrm{bp}$ with micropropagated plant, lane (2), and 800 and $205 \mathrm{bp}$ with mother plant, lane (1) (Fig. 5a). With regard to the results, it could be observed that primer AM2 produced a polymorphism percentage of 28.57, recording 4 polymorphic bands out of 14 amplification products (Fig. 5b). The 4 bands were absent bands at molecular sizes of 1456, 812, and $506 \mathrm{bp}$ in the regenerated plant (lane 3) and at $450 \mathrm{bp}$ in the mother plant (lane 1). In addition, with primer AM3, 3 polymorphic bands out of 23 scorable bands were detected representing polymorphism percentage of 13.04 (Fig. 5c). Two of them were absent in mother plant A1 (lane 1) with molecular weights of 1436 and $1014 \mathrm{bp}$, and one was present at the molecular size of $681 \mathrm{bp}$ in the micropropagated plant B1 (lane 2). Moreover, primer AM4 produced 5 polymorphic bands out of 27 scorable bands, representing polymorphism percentage of 18.52 (Fig. $5 \mathrm{~d})$. Out of these 5 bands, 3 were absent in micropropagated plant B1 (lane 2) at molecular sizes of 1571, 808, and $318 \mathrm{bp}$; one was absent in mother plant A1 (lane 1) at molecular size of $919 \mathrm{bp}$. Moreover, one band was present in mother plant A1 (lane 1) at a molecular size of $716 \mathrm{bp}$. Using primer AM5 resulted in 7 polymorphic bands out of 22 scorable bands, representing a polymorphism percentage of 31.82 . Out of them, 4 were absent in regenerated plant $\mathrm{C} 1$ (lane 3) at molecular sizes of 1571, 874, 765, and 438. Moreover, two bands were absent in the micropropagated plant B1 (lane 2) at molecular sizes of 1151 and 1000 bp (Fig. 5). Finally, one band was present at molecular size of $733 \mathrm{bp}$ in mother plant A1 (lane 1) (Fig. 5e).

\section{Discussion}

The best treatment for callus induction from leaf explant of $J$. curcas were MS medium supplemented with 2.5 $\mathrm{mg} / \mathrm{l} \mathrm{BA}$ and $1.0 \mathrm{mg} / \mathrm{l} \mathrm{NAA}$. In this respect, Rajore and Batra (2007) induced callus from leaf explants of $J$. curcas by culturing it on MS media supplemented with 1.0 $\mathrm{mg} / \mathrm{l} \mathrm{NAA}$ and $5.0 \mathrm{mg} / \mathrm{l} \mathrm{BAP}$. Moreover; Kumar et al. (2008) cultured leaf explant of $J$. curcas on MS medium supplemented with $5 \mathrm{mg} / \mathrm{l} \mathrm{BAP}$ and $1 \mathrm{mg} / \mathrm{l} \mathrm{NAA}$ obtaining a friable callus that used for evaluation of dry and fresh mass of the grown callus. Yan Bi et al. (2009) showed that the best medium for callus induction from cotyledon of $J$. curcas plant was MS medium supplemented with $2.0 \mathrm{mg} / \mathrm{l} \mathrm{BA}$ in combination with $2.0 \mathrm{mg} / \mathrm{l}$ NAA. Also, Mohanalakshmi et al. (2009) obtained callus when they subcultured different explants of $J$. curcas on MS supplemented with $1.5 \mathrm{mg} / \mathrm{l} \mathrm{BA}$ only, while Varshney and Johnson (2010) showed that MS medium supplemented with $0.5 \mathrm{mg} / \mathrm{l} \mathrm{IBA}$ and $1.0 \mathrm{mg} / \mathrm{l} \mathrm{BA}$ was the best medium for callus induction from immature embryos of $J$. curcas giving a response of morphogenic callus induction (85.7\%). Moreover, Meng Ji et al. (2010) 
Table 5 ISSR-PCR amplification products of DNA extracted from different samples of J. curcas plants using different five ISSR primers

\begin{tabular}{|c|c|c|c|c|c|}
\hline Primer code & $\begin{array}{l}\text { Primer sequence } \\
5^{\prime} \text {----- } 3^{\prime}\end{array}$ & $\begin{array}{l}\text { Total number } \\
\text { of scorable bands }\end{array}$ & $\begin{array}{l}\text { Number of monomorphic } \\
\text { bands }\end{array}$ & $\begin{array}{l}\text { Number of polymorphic } \\
\text { bands }\end{array}$ & Polymorphism (\%) \\
\hline$\overline{A M 1}$ & СтСТСТСТСТСтСТСTG & 30 & 24 & 3 & 10 \\
\hline AM2 & GGATGGAATAGTCTC & 14 & 6 & 4 & 28.57 \\
\hline AM3 & GCATGGCAAGCTGCA & 23 & 18 & 3 & 13.04 \\
\hline AM4 & GAGAGAGAGAGAGAGAC & 27 & 18 & 5 & 18.52 \\
\hline AM5 & ACACACACACACACACC & 22 & 9 & 7 & 31.82 \\
\hline Overall totals & --- & 116 & 75 & 22 & 18.96 \\
\hline
\end{tabular}

Polymorphism \% = (number of polymorphic bands/total number of scorable bands) $\times 100$

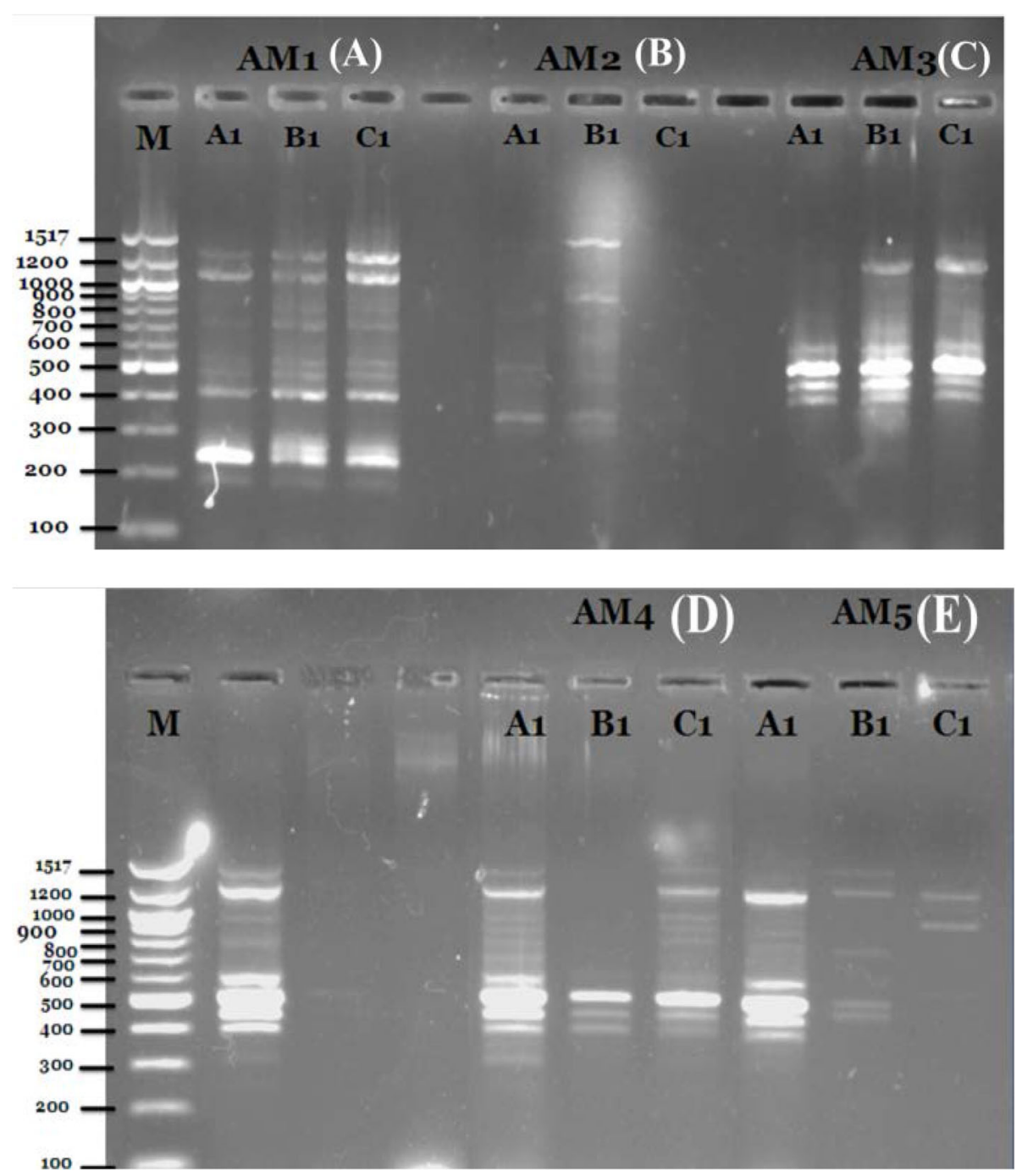

Fig. 5 Agarose gel electrophoresis of inter simple sequence repeat (ISSR) fragments. Lane 1 (A1) refers to mother plants, lane 2 (B1) refers to in vitro propagated plants, lane 3 (C1) refers to plants regenerated from callus, and lane $\mathrm{M}$ indicates molecular weight DNA ladder given in bp (100-1517). Polymorphic DNA fragments are identified by an arrowhead 
showed that $0.5 \mathrm{mg} / \mathrm{l} \mathrm{BA}+0.1 \mathrm{mg} / \mathrm{l} 2,4-\mathrm{D}$ was the best medium for callus induction rate $(96.7 \%)$ from $J$. curcas. Misra et al. (2010) reported that the optimum treatment for callus induction in leaf segments of $J$. curcas plants was $0.5 \mathrm{mg} / \mathrm{l} \mathrm{BA}$ with $1.0 \mathrm{mg} / \mathrm{l}$ each of 2,4-D and IAA obtaining both types of calli (green and compact; yellow and friable), and they were employed for shoot organogenesis. Also, Ranwah et al. (2009) observed a green callus when they incubated leaf discs of J. curcas on MS medium supplemented with $10 \mathrm{mg} / \mathrm{l}$ BAP in combination with $5 \mathrm{mg} / \mathrm{l} \mathrm{IBA}$. Moreover, by sub-culturing on the same medium, they found that the quantity of callus was increased.

Different authors reported the regeneration of plantlets from different explants of $J$. curcas when explants were cultured on different media. In this connection, Sardana et al. (2000) obtained embryogenic callus from leaf explants of $J$. curcas. They noticed the formation of plantlets when the embryogenic callus was cultured on MS medium supplemented with $3.0 \mathrm{mg} / \mathrm{l} \mathrm{GA}_{3}$ in combination with $1.0 \mathrm{mg} / \mathrm{l} \mathrm{IAA}$. Also, Sharma et al. (2006) obtained shoot buds from callus tissues when grown on MS medium supplemented with $0.5 \mathrm{mg} / \mathrm{l} \mathrm{NAA}$ and 0.06 $\mathrm{mg} / \mathrm{l}$ zeatin. Moreover, Rajore and Batra (2007) used green compact nodules of callus tissues and found that MS medium supplemented with $1.5 \mathrm{mg} / \mathrm{l} \mathrm{BAP}$ and 0.5 $\mathrm{mg} / \mathrm{l}$ IBA was the best combination for shoot bud induction and elongation. In addition, Thepsamran et al. (2008) reported that MS medium supplemented with $1.0 \mathrm{mg} / \mathrm{l} \mathrm{BA}$ in combination with $0.5 \mathrm{mg} / \mathrm{l} \mathrm{IBA}$ was the best medium for regeneration of adventitious shoots from callus induced from petioles of leaves of J. curcas. In addition, our results are in agreement with Verma et al. (2008). They induced callus from petiole explants of $J$. curcas and found that MS medium supplemented with $0.25 \mathrm{mg} / \mathrm{l} \mathrm{IBA}$ in combination with $2.0 \mathrm{mg} / \mathrm{l} \mathrm{BAP}$ was the best medium for shoot regeneration (75\%) from callus tissues. Also, regenerated adventitious shoots of $J$. curcas was obtained from induced callus tissues (Mohanalakshmi et al. 2009). They reported that MS medium supplemented with $1.0 \mathrm{mg} / \mathrm{l} \mathrm{BA}+1.5 \mathrm{mg} / \mathrm{l} \mathrm{NAA}$ was the best medium for regeneration of adventitious shoots. Recently, BoBin et al. (2010) found that the best combination for callus induction and induction of adventitious shoot buds (75.8\%) was MS medium supplemented with $5.0 \mathrm{mg} / \mathrm{l} \mathrm{BA}$ and $0.5 \mathrm{mg} / \mathrm{l} \mathrm{IBA}$.

Regarding RAPD analysis, the present results were in common with those obtained by many researchers. In this respect, Yadav and Shukla (2010) assessed the genetic diversity among different 20 genotypes of $J$. curcas plants using 20 random RAPD primers showing 158 reproducible bands. Each of LC-77, LC-84, and LC-96 primers produced about 4 bands, whereas LC-89 primer produced about 22 bands with an average of 7.9 bands per primer. Each primer showed $100 \%$ of polymorphism. Moreover, Subramanyam et al. (2010) assessed the genetic diversity and pedigree of 10 accessions of $J$. curcas, collected from different Indian regions. Ten selected primers produced 125 bands from which 76 were polymorphic bands. Each primer produced an average 12.5 bands, of which 7.6 were polymorphic bands. Also, Ikbal et al. (2010) used RAPD technique utilizing 50 random primers to assess the genetic diversity among different accessions of $J$. curcas collected from different ecogeographical Indian regions. From which 44 primers produced 308 polymorphic bands out of 328 . The polymorphism was scored and used in band sharing analysis to identify genetic relationship.

Sharma et al. (2011) studied the genetic stability of in vitro J. curcas plantlets regenerated from axillary buds obtained from selected high-yielding genotypes using RAPD analysis. Out of 52 screened RAPD primers, 21 primers gave clear reproducible bands. In the micropropagated plantlets, 4 bands out of 177 scorable bands were polymorphic within the 2nd sub-culture, whereas no polymorphisms were detected in the 8th and 16th sub-cultures. They concluded that axillary shoot proliferation can safely be used as an efficient micropropagation method for mass propagation of J. curcas giving a high genetic stability for micropropagated plantlets of $J$. curcas. Also, Mastan et al. (2012) used the RAPD technique to assess the genetic diversity among elite germplasms of J. curcas. They found that, out of 250 amplicons, 141 found to be polymorphic using 26 RAPD primers. Polymorphism percentage among the selected germplasms using RAPD was found to be 56.43. Recently, Gautam Murty et al. (2013) evaluated the genetic diversity of 19 Jatropha accessions using RAPD in combination with ISSR and DAMD techniques. RAPD analysis produced a polymorphism percentage of 96.67 .

Data of unique markers revealed by RAPD analysis of the tested J. curcas samples showed that primer AM8 exhibited the highest number of unique markers (7) mentioned as the following: two with in vivo plant 1 (A1), one with in vivo plant 2 (A2), one with in vitro plant 2 (B2), 2 with regenerated plant 1 (C1), and 1 with regenerated plant $2(\mathrm{C} 2)$. The lowest number of unique markers (3) was exhibited with primers AM7 and AM9. All unique markers with AM7 appeared with in vivo plant 1 (A1), while 2 unique markers appeared with in vivo plant 1 (A1) and one with regenerated plant 2 (C2) for primer AM9. Six unique markers appeared with each of primers $\mathrm{C} 12$ and A6. Many authors reported that RAPD-PCR markers gave adequate distinctions among all the tested cultivars of different crops. In this respect, Adawy and El-Sherbieny (1999) studied genotype identification and genetic distance among maize inbred lines using RAPD markers. They identified 28 
unique markers distributed among maize inbred lines from three populations. Abdel-Tawab et al. (2001) found some unique bands which could be used as a DNA marker for cultivar identification in sweet sorghum. Also, El-Khishin et al. (2003) surveyed 20 maize inbred lines using 40 RAPD markers, and 21 of them gave unique markers which identified individual lines from each other.

Many workers used RAPD as a tool for determining the extent of genetic diversity among different crops and for allocating genotypes into different groups. In this connection, Ram et al. (2008) studied the genetic diversity of 12 species of Jatropha and reported that Jaccard's similarity coefficient indicated a high level of genetic variance among studied genotypes as it varied from 0.00 to 0.85 . Three main clusters was indicated by UPGMA cluster analysis, one including all accessions of J. curcas, while the second included six species, and the third cluster contained 2 species, indicating its higher genetic distinctness from other species.

Jubera et al. (2009) studied the genetic variation in seven genotypes of $J$. curcas using RAPD analysis. They found that Jaccard's similarity coefficient showed a high genetic similarity among studied genotypes as it ranged from 81.8 to 100 . Dendrogram analysis showed two main clusters of the seven studied genotypes. Also, Subramanyam et al. (2009) used RAPD technique to identify the genetic diversity in 40 accessions of $J$. curcas. They reported that Jaccard's similarity coefficient varied from 0.00 to 1.00 , indicative of high levels of genetic variation among the genotypes studied, whereas cluster analysis of data using UPGMA algorithm placed the 40 accessions into 2 main clusters, with cluster II divided into six subclusters. Sarkar et al. (2010) used the RAPD technique to identify the polymorphism in J. curcas plants raised in vitro from leaf explants. The dendrogram analysis showed three groups, A, B, and C. One hundred percent genetic similarity was detected within group A samples, whereas a higher genetic variance was detected between samples from groups $B$ and $C$ as compared to samples from A and B as well as A and C. Moreover, Ikbal et al. (2010) studied the genetic diversity among different accessions of $J$. curcas. Cluster analysis based on Jaccard's similarity coefficient using UPGMA grouped all the 40 genotypes into two major groups at a similarity coefficient of 0.54 . Similarity indices ranged from 0.44 to 0.92 with an average of 0.73 , indicating a moderate to high genetic variability among the genotypes. Recently, Alkimim et al. (2013) estimated the genetic diversity among 46 accessions of $J$. curcas using Nei and Li's similarity coefficient based on 69 RAPD primers and ISSR technique. The genetic distance between accessions ranged from 0.13 to 0.76 . The most divergent genotypes were 86,71 , and 83. A dendrogram based on UPGMA of the joint data matrix presented only two phylogenetic groups, one of which contained only three individuals; the remaining group included $95.6 \%$ of the analyzed genotypes.

The results of this study could identify polymorphic ISSR markers that could distinguish between mother plant and tissue culture-raised plants. The current study with ISSR markers has revealed a low level of polymorphism between the tested samples. In this respect, Cai et al. (2010) studied the genetic diversity of Chinese Jatropha germplasm using ISSR markers. They found 127 polymorphic bands out of 169 amplified bands producing a polymorphism pecentage of 75.15. Also, Grativol et al. (2011) studied the genetic diversity of 332 Brazilian J. curcas accessions using ISSR markers. Seven ISSR primers produced 21,253 amplified bands out of which 19472 were polymorphic producing 91\% polymorphism. In addition, Arolu et al. (2012) used 10 ISSR primers for characterization of $48 \mathrm{~J}$. curcas Malaysian accessions. They reported that the polymorphism pecentage ranged from 90.75 to 100 . Camellia et al. (2012) used 8 ISSR primers for evaluation of genetic relationship among 16 accessions of $J$. curcas. They found that 25 polymorphic bands out of 63 amplified bands resulting in $40 \%$ polymorphism. Moreover, Khurana-Kaul et al. (2012) used 25 ISSR primers to assess the genetic relationships of $29 \mathrm{~J}$. curcas accessions and found that the polymorphism percentage was 59.8. Recently, Biabani et al. (2013) employed 10 ISSR primers to assess the genetic diversity among 6 populations of Jatropha from different Asian countries. One hundred forty-three polymorphic bands were produced, and the polymorphism pecentage ranged between 46.2 and 60.8 between the different genotypes. Generally, most workers obtained high percentage of polymorphism, and this may be because of the analysis of different species and genotypes of Jatropha from different regions. But in this study, low polymorphism percentage was detected in comparison to other workers. This may be due to the analysis of samples in the same genotypes of $J$. curcas (mother, micropropagated, and regenerated) plants.

\section{Conclusion}

An optimized protocol for large-scale production of J. curcas plants using plant biotechnology tools was achieved. RAPD and ISSR techniques would introduce an alternative system for large-scale production and establishment of genetically stable plants.

Abbreviations

RAPD: Randomly amplified polymorphic DNA; ISSR: Inter simple sequence repeat; NAA: 1-Naphthaleneacetic acid; BA: 6-Benzylaminopurine; IBA: Indole3-butyric acid 


\section{Acknowledgements}

The authors would like to thank the National Research Centre (NRC) for its facilities during this scientific work.

\section{Authors' contributions}

UA and MR conceptualized the research and designed the experiments. ME conducted the research. UI, MR, and MS wrote the manuscript. All authors read and approved the final manuscript.

\section{Funding}

No specific fund was supplied for this work.

\section{Availability of data and materials}

The data sets supporting the results are included within the article.

\section{Ethics approval and consent to participate}

The manuscript does not contain studies involving human participants, human data, or human tissue.

\section{Consent for publication}

The authors declare that the work has consent for publication.

\section{Competing interests}

The authors declare that they have no competing interests.

\section{Author details}

'Plant Biotechnology Department, National Research Center, 33 El Bohouth St., Dokki, Cairo, P.O 12622, Egypt. ${ }^{2}$ Chemistry Department, Faculty of Science, Cairo University, Cairo, Egypt.

\section{Received: 11 December 2019 Accepted: 14 April 2020}

Published online: 06 May 2020

\section{References}

Abdel-Tawab FM, Abo-Doma A, Allam Al, El-Rashedy HA (2001) Assessment of genetic diversity for eight sweet sorghum cultivars (Sorghum bicolor L.) using RAPD analysis. Egypt. J. Geney Cytol 30(1):41-50

Adawy SS, El-Sherbieny HY (1999) Genotype identification and estimation of genetic distance among elite maize inbred lines using RAPD markers. Proc. Of VI National Conference for Environmental Studies and Research, Egyptian Desert Environmental Development, Ain-Shams Univ., Institute of Environmental Studies and Research. Nov., 7- 9: 245- 260

Alkimim ER, Sousa TV, Soares BO, Souza DA, Juhász ACP, Nietsche S, Costa MR (2013) Genetic diversity and molecular characterization of physic nut genotypes from the active germplasm bank of the Agricultural Research Company of Minas Gerais, Brazil. Afr J Biotechnol 12(9):907-913

Arolu IW, Rafii MY, Hanafi MM, Mahmud TMM, Latif MA (2012) Molecular characterization of Jatropha curcas germplasm using inter simple sequence repeat (ISSR) markers in Peninsular Malaysia. Aust J of Crop Sci 6(12):16661673

Basha SD, Francis G, Makkar HPS, Becker K, Sujatha M (2009) A comparative study of biochemical traits and molecular markers for assessment of genetic relationships between Jatropha curcas L. germplasm from different countries. Plant Sci 176(6):812-823

Biabani A, Rafii MY, Saleh GB, Abdul Latif M (2013) Inter- and intra-population genetic variations in Jatropha curcas populations revealed by inter-simple sequence repeat molecular markers. Maydica 58:111-118

BoBin L, Meng Zhu L, Ling L, JieNan C (2010) The study of high-efficiency plant regeneration of Jatropha curcas. J Forest Res Beijing 23(3):326-329

Cai Y, Sun D, Wu G, Peng J (2010) ISSR-based genetic diversity of Jatropha curcas germplasm in China. Biomass Bioener 34:1739-1750

Camellia NAN, Lee AT, Abdullah NAP (2012) Genetic relationships and diversity of Jatropha curcas accessions in Malaysia. Afr J Biotechnol 11(13):3048-3054

Doyle JJ, Doyle JL (1990) Isolation of plant DNA from fresh tissue. Focus 12:13-15

El-Khishin D, Abdel-Hamid A, El-ltriby H, Ahmed FA, Abdel Raihem EA (2003) Estimates of genetic similarities and relationships among Egyptian maize inbreds using RAPD and AFLP markers. Egyptian J Genet Cytol 32:1-23

Gautam Murty S, Patel F, Punwar BS, Patel M, Singh AS, Fougat RS (2013) Comparison of RAPD, ISSR, and DAMD markers for genetic diversity assessment between accessions of Jatropha curcas $L$. and its related species. J Agr Sci Tec. 15:1007-1022
Grativol C, da Fonseca L-MC, Hemerly AS, Ferreira PCG (2011) High efficiency and reliability of inter-simple sequence repeats (ISSR) markers for evaluation of genetic diversity in Brazilian cultivated Jatropha curcas L accessions. Mol Biol Rep 38:4245-4256

Gupta S, Srivastava M, Mishra GP, Naik PK, Chauhan RS, Tiwari SK, Kumar M, Singh R (2008) Analogy of ISSR and RAPD markers for comparative analysis of genetic diversity among different Jatropha curcas genotypes. African J Biotechnol 7(23):4230-4243

Ikbal K, Boora S, Dhillon RS (2010) Evaluation of genetic diversity in Jatropha curcas L. using RAPD markers. Indian J Biotechnol 9(1):50-57

Jaccard P (1908) Nouvelles recherches sur la distribution florale. Bull Soc Vaudense Sci Nat 44:223-270

Jubera MA, Janagoudar BS, Biradar DP, Ravikumar RL, Koti RV, Patil SJ (2009) Genetic diversity analysis of elite Jatropha curcas (I.) genotypes using randomly amplified polymorphic DNA markers. Karnataka J Agric Sci 22(2): 293-295

Khurana-Kaul V, Kachhwaha S, Kothari S (2012) Characterization of genetic diversity in Jatropha curcas L germplasm using RAPD and ISSR markers, Indian J Biotechnol 11:54-61

Kumar N, Pamidimarri SDVN, Kaur M, Boricha G, Reddy MP (2008) Effects of NaCl on growth, ion accumulation, protein, proline contents and antioxidant enzymes activity in callus cultures of Jatropha curcas. Biologia 63(3):378-382

Li K, Yang WY, Li L, Zhang CH, Cui YZ, Sun YY (2007) Distribution and development strategy for Jatropha curcas L. For Stud China 9(2):120-126

Li Z, Nelson RL (2002) RAPD marker diversity among cultivated and wild soybean accessions from four Chinese provinces. Crop Sci 42:1737-1744

Mastan SG, Sudheer PDVN, Rahman H, Ghosh A, Rathore MS, Prakash CR, Chikara J (2012) Molecular characterization of intra-population variability of Jatropha curcas L. using DNA based molecular markers. Mol Biol Rep 39:4383-4390

Meng Ji Q, YinShan H, Liu Shuang T, Ji L (2010) The callus of physic nut (Jatropha curcas L.) induced. J Genomics Appl Biol 29(1):191-194

Misra P, Gupta N, Toppo DD, Pandey V, Mishra MK, Tuli R (2010) Establishment of long-term proliferating shoot cultures of elite Jatropha curcas L. by controlling endophytic bacterial contamination. Plant Cell Tiss Organ Cult 100(2):189-197

Mohanalakshmi M, Vadivel E, Ganga M (2009) Standardisation of protocol for Jatropha curcas. Int J Agric Env Biotechnol 2(4):429-431

Murashige T, Skoog F (1962) A revised medium for rapid growth and bioassays with tobacco tissue cultures. Physio Plant 15:473-497

Nitish K, Muppala PR (2013) Jatropha tissue culture: a critical review on present scenario and future prospects. In: Bahadur B et al (eds) Jatropha, Challenges for a New Energy Crop: Volume 2: 513 Genetic Improvement and Biotechnology. @ Springer Science, Business Media, New York. https://doi. org/10.1007/978-1-4614-4915-7_26

Rady MR, El-Sayed M, Mervat MS, Aly UI (2016) Influence of plant growth regulators and medium strength on micropropagation of biodesel plant, Jatropha curcus. Plant Tiss Cult Biotech 26(1):85-96

Rajore S, Batra A (2007) An alternative source for regenerable organogenic callus induction in Jatropha curcas L. Indian J Biotechnol 6(4):545-548

Ram SG, Parthiban KT, Senthil Kumar R, Thiruvengadam V, Paramathma M (2008) Genetic diversity among Jatropha species as revealed by RAPD markers. Genet Resour Crop Evol 55:803-809

Ranwah BR, Gupta DK, Shah MA (2009) Micropropagation of Jatropha curcas (L.). Indian J Agric Res 43(4):269-273

Sardana J, Batra A, Ali DJ (2000) An expeditious method for regeneration of somatic embryos in Jatropha curcas L. J Phytomorphol (3/4):239-242

Sarkar T, Anand KGV, Reddy MP (2010) Effect of nickel on regeneration in Jatropha curcas L. and assessment of genotoxicity using RAPD markers. J Biometals 23:1149-1158

Sharma A, Kansal N, Shekhawat GS (2006) In vitro culture and plant regeneration of economically potent plant species Jatropha curcas. Biochem Cell Arch 6(2): 323-327

Sharma S, Sudheer PDVN, Anand KGV, Reddy MP (2011) Assessment of genetic stability in micropropagules of Jatropha curcas genotypes by RAPD and AFLP analysis. Industrial Crops Prod 34:1003-1009

Soller M, Beckmann JS (1983) Genetic polymorphism in varietal identification and genetic improvement. Theor Appl Genet 67:25-33

Subramanyam K, Muralidhararao D, Devanna N (2009) Genetic diversity assessment of wild and cultivated varieties of Jatropha curcas (L.) in India by RAPD analysis. Afr J Biotechnol 8(9):1900-1910 
Subramanyam K, Rao DM, Devanna N, Aravinda A, Pandurangadu V (2010) Evaluation of genetic diversity among Jatropha curcas (L.) by RAPD analysis. Indian J Biotechnol 9(3):283-288

Thepsamran N, Thepsithar C, Thongpukdee A (2008) In vitro induction of shoots and roots from Jatropha curcas L. explants. J Horticult Sci Biotechnol 83(1): $106-112$

Van der Nest MA, Steenkamp ET, Wingfield BD, Wingfield MJ (2000) Development of simple sequence repeat (SSR) markers in Eucalyptus from amplified inter-simple sequence repeats (ISSR). Plant Breed 119:433-436

Varshney A, Johnson TS (2010) Efficient plant regeneration from immature embryo cultures of Jatropha curcas, a biodiesel plant. Plant Biotechnol Rep 4(2):139-148

Verma KC, Gaur AK, Singh US (2008) Evaluation of in vitro responses from different explants of elite Jatropha curcas L. Indian J Plant Physiol 3:231-237

Williams JGK, Kubelik AR, Livak KJ, Rafalski JA, Tingey SV (1990) DNA polymorphisms amplified by arbitrary primers are useful as genetic markers. Nucleic Acids Res 18:6531-6535

Yadav NS, Shukla A (2010) Molecular diversity in Jatropha curcas (L.) genotypes assessed by RAPD markers. Pantnagar J Res 8(1):32-38

Yan Bi D, Hua C, Hun G (2009) Preliminary study on the tissue culture of Jatropha curcas L. J Yunnan Agric Univ 24(1):26-29

\section{Publisher's Note}

Springer Nature remains neutral with regard to jurisdictional claims in published maps and institutional affiliations.

\section{Submit your manuscript to a SpringerOpen ${ }^{\circ}$ journal and benefit from:}

- Convenient online submission

- Rigorous peer review

- Open access: articles freely available online

- High visibility within the field

- Retaining the copyright to your article

Submit your next manuscript at $\boldsymbol{\nabla}$ springeropen.com 